\title{
EFEKTIVITAS PROGRAM PENDIDIKAN AUTISMA LONDON SCHOOL BEYOND ACADEMY (LSBA) DALAM MEMPERSIAPKAN INDIVIDU AUTISMA SIAP KERJA
}

\author{
Erni Adi Astuti1, Hotner Tampubolon², Nurul Hidayah ${ }^{3}$ \\ ${ }^{1}$ Mahasiswa Magister Administrasi Pendidikan PPs-UKI, Jakarta, Indonesia, ${ }^{2}$ Dosen Magister \\ Administrasi Pendidikan PPs -UKI, Jakarta Indonesia, ${ }^{3}$ London School of Public Relations, Jakarta, \\ Indonesia \\ e-mail: witarsa.oke@gmail.com \\ hotnertampubolon@yahoo.com
}

\begin{tabular}{l|l|l} 
Received : Januari, 2021 & Accepted : Januari, 2021 & Published : Januari, 2021
\end{tabular}

\begin{abstract}
This research are conducted to explore the curriculum planning, to expose the implementation of the curriculum in LSBA that is effective for individuals with autism, to determine the process of monitoring teaching and learning activities and to determine the process of evaluating the results of teaching and learning activities at LSBA. The research method used is descriptive with a qualitative approach, which is describing the data obtained from the field and explaining in words. This study aims to find what the most effective program for individuals with autism who graduated from high school. In addition, this study explores more deeply the implementation of the curriculum and the learning techniques applied in the London School Beyond Academy (LSBA). This research found that the effectiveness of curriculum planning, the effectiveness of curriculum implementation carried out properly during teaching and learning activities in class, the effectiveness of monitoring teaching and learning activities carried out is in accordance with the program planning but the additional term of study is needed and the effectiveness of the evaluation of teaching and learning activities has been carried out well in LSBA for individuals with autism. The conducted reearch also found that the program implemented at LSBA is effective for individuals with autism who are ready to work with the skills they have after studying in LSBA. The more effective the educational program, the more it will support individuals with autism ready to work according to their respective abilities.
\end{abstract}

Keywords: education program effectiveness, planning, implementation, monitoring, evaluation, individuals with autism

\begin{abstract}
Abstrak
Penelitian ini dilakukan dengan tujuan untuk mengetahui perencanaan kurikulum di LSBA sehingga tepat bagi individu autisma, untuk mengetahui implementasi kurikulum di LSBA sehingga tepat bagi individu autisma, untuk mengetahui proses monitoring kegiatan belajar mengajar di LSBA dan untuk mengetahui proses evaluasi hasil kegiatan belajar mengajar di LSBA. Adapun metode penelitian yang digunakan oleh peneliti dalam penulisan ini adalah berbentuk deskriptif dengan pendekatan kualitatif yaitu menggambarkan data yang didapat dari lapangan dan menjelaskannya dengan kata-kata. Penelitian ini bertujuan untuk mengetahui program apa yang paling tepat bagi individu
\end{abstract}


autisma selepas SMA selain itu penelitian ini menggali lebih dalam implementasi dari kurikulum yang diterapkan serta teknik pembelajaran yang dilakukan oleh London School Beyond Academy (LSBA). Dari penelitian yang telah dilaksanakan ditemukan hasil efektivitas perencanaan kurikulum yang dilaksanakan di LSBA bagi individu autisma, efektivitas implementasi kurikulum dimana semua dapat terlaksana dengan baik selama kegiatan belajar mengajar di kelas, efektivitas monitoring kegiatan belajar mengajar yang dilakukan sudah sesuai dengan perencanaan program namun diperlukan penambahan waktu yang lebih lama dan efektivitas evaluasi kegiatan belajar mengajar sudah dilaksanakan dengan baik di LSBA. Setelah dilaksanakan penelitian ini dilapangan maka dapat ditemukan bahwa program yang dilaksanakan di LSBA ini efektif bagi individu autisma siap bekerja dengan adanya keterampilan yang dimiliki setelah belajar di LSBA. Semakin efektif program pendidikan maka semakin menjadikan individu autisma siap bekerja sesuai dengan kemampuannya masing - masing.

Kata Kunci: efektivitas program pendidikan, perencanaan, implementasi, monitoring, evaluasi, individu autisma

Citation: Astuti, E. A., Tampubolon, H., \& Hidayah, N. (2021). EFEKTIVITAS PROGRAM PENDIDIKAN AUTISMA LONDON SCHOOL BEYOND ACADEMY (LSBA) DALAM MEMPERSIAPKAN INDIVIDU AUTISMA SIAP KERJA.Jurnal Manajemen Pendidikan,10(1), 46-56. Retrieved from http://ejournal.uki.ac.id/index.php/imp/article/view/3266

\section{PENDAHULUAN}

Keberadaan individu berkebutuhan khusus telah menjadi perhatian pemerintah Indonesia. Hal ini nampak pada UU yang menyatakan karakter individu berkebutuhan khusus serta kategorisasinya yaitu dikatakan dalam UU no 8 tahun 2016 pasal 1 dinyatakan bahwa Penyandang Disabilitas adalah setiap orang yang mengalami keterbatasan fisik, intelektual, mental, dan/atau sensorik dalam jangka waktu lama yang dalam berinteraksi dengan lingkungan dapat mengalami hambatan dan kesulitan untuk berpartisipasi secara penuh dan efektif dengan warga negara lainnya berdasarkan kesamaan hak.

Perhatian tersebut tentunya berdampak pada hak individu berkebutuhan khusus dalam hal kesehatan, berkewarganegaraan, keadilan, hingga pendidikan. Pertambahan jumlah Individu berkebutuhan khusus di Indonesia saat ini terus melaju, seperti yang dituliskan dalam Badan Pusat Statistik tahun 2017 jumlah anak berkebutuhan khusus (ABK) di Indonesia mencapai angka 1,6 juta anak (Kementerian Pendidikan dan Kebudayaan Indonesia, 2017). Mengacu pada kategori disabilitas yang ditentukan oleh pemerintah Indonesia terdapat individu Autisma didalamnya, yaitu mereka yang memiliki kesulitan jangka panjang atau menetap pada proses berinteraksi sosial. Autisma yang memiliki ciri khas kesulitan berkomunikasi, menyendiri, memiliki gangguan sensori, gangguan sensori, gangguan perilaku dan juga rigid baik suara maupun cahaya dan juga tempat yang baru pada kenyataannya terkadang menghadapi berbagai macam kesulitan dalam lingkungan sosial. Kondisi fisik yang tidak nampak berbeda menjadikan lingkungan sulit untuk membedakan keterbatasan yang ada.

Masalah yang dihadapi oleh orang tua anak autisma terkadang bukan hanya pada ketidakpahaman dalam lingkungan sosial saja, tetapi juga terjadi ketika bersinggungan dengan unsur pendidikan. Mencari sekolah dengan lingkungan yang 'aman' tidaklah mudah. Pemerintah telah membantu dengan memberikan peraturan penerimaan siswa berkebutuhan khusus pada seluruh sekolah negeri di Indonesia, tetapi hal tersebut masih jauh dari kondisi ideal sebuah lembaga pendidikan yang bersifat inklusi. Kesiapan sebuah sekolah inklusi bukan hanya pada faktor guru saja, tetapi juga lingkungan belajar lainya seperti teman, kurikulum, metode belajar, dan fasilitas.

Melihat fenomena tersebut peneliti telah mengikuti sebuah kegiatan sosialisasi mengenai autism bagi siswa sekolah dasar negeri di Jabodetabek. Peneliti menjumpai terdapat 1 hingga 2 siswa 
autisma dalam setiap kelas, artinya dalam 1 sekolah terdapat 6 hingga 10 siswa. Kondisi yang terjadi adalah tidak jarang Kepala sekolah serta guru tidak memahami kondisi siswa autism. Hal ini diperburuk dengan orang tua yang tidak mengerti bahwa anaknya adalah autisma. Ketidakpahaman tersebut menjadikan muncul keluhan dari guru dan orang tua bahwa siswa atau anak tidak bisa bicara, terlalu aktif, dan berperilaku tidak seperti anak pada umumnya, sehingga sering kali dicap nakal atau bandel.

Apabila anak autisma dari awal tidak mendapatkan penanganan khusus, maka kesulitan dan kekurangan mereka tidak akan tertangani dengan baik sehingga mereka akan berperilaku tidak seperti pada umumnya di masyarakat, tidak memahami bahasa, emosi tidak tertata dengan baik, perilaku yang agak aneh dan tidak terlihat seperti anak pada umumnya. Apabila emosi mereka yang tidak stabil tersebut tidak ditangani khusus, maka mereka akan menyampaikan dengan bahasa mereka sendiri yaitu apabila apa yang mereka inginkan tidak terpenuhi, mereka akan marah atau memberontak misalnya dengan berteriak, menangis bahkan apabila mereka tidak suka akan membuang barang. Bisa dibayangkan apabila mereka tidak mendapatkan penanganan yang khusus dan baik dari awal, saat dewasa mereka akan berperilaku semaunya mereka tidak sesuai dengan aturan dan kaidah di masyarakat pada umumnya.

Yang melatarbelakangi ketertarikan untuk meneliti permasalahan ini yaitu masih langkanya pendidikan anak berkebutuhan khusus di Indonesia terutama anak autisma selepas Sekolah Menengah Atas (SMA) yang memasuki usia remaja. Banyak orang tua yang memiliki anak autisma merasa gelisah dan bingung dengan putra-putri mereka setelah selepas Sekolah Menengah Atas (SMA) harus sekolah kemana lagi. Hal ini dikarenakan karakteristik anak-anak autisma yang mengalami kesulitan dalam berinteraksi sosial, berkomunikasi, ketidakstabilan emosi, kesulitan dalam perilaku sehingga mengakibatkan mereka tidak dapat bergaul seperti anak pada umumnya dan membuat mereka sulit untuk dapat melanjutkan sekolah regular atau kuliah regular yang lebih tinggi lagi. Walaupun ada satu atau dua anak autisma tercacat secara kemampuan dan memiliki perilaku yang sudah baik dapat melanjutkan ke jenjang perguruan tinggi regular namun masih terlihat ciri - ciri perilaku autisma itu sendiri misalnya lebih suka menyendiri, berkata - kata dengan bahasa yang sangat baku dan juga kurang fleksibel dalam berinteraksi dengan lingkungan sehingga terlihat mereka sangat kaku di lingkungan masyarakat.

Kegelisahan orang tua yang memiliki anak autisma ini sangat wajar dikarenakan masih kurangnya sekolah di Indonesia yang menampung anak - anak autisma usia remaja selepas Sekolah Menengah Atas (SMA). Kegelisahan tersebut tidak cukup sampai dengan disitu, namun juga saat putra - putri mereka memasuki usia produktif atau usia bekerja mereka akan bekerja dimana dan bekerja apa, bagaimana nanti kehidupan mereka seandainya orang tua sudah tidak ada, apakah mereka bisa hidup baik atau apakah masyarakat dapat menerima mereka dengan segala kekurangan yang mereka miliki. Masa depan anak - anak autisma ini menjadi pemikiran dari banyak orang tua yang memiliki anak autisma. London School Beyond Academy (LSBA) merupakan tempat belajar remaja - remaja autisma yang telah lulus SMA yang merupakan tempat yang selama ini dicari - cari oleh orang tua yang memiliki anak autisma dan mau kuliah. Di LSBA ini ada jurusan yang tersedia yaitu Kriya Tekstil, Tehnik Cetak \& Digital Image, Administrasi Perkantoran ini 85\% praktek dan 15\% teori. Hal ini dilakukan dikarenakan individu autisma akan lebih mudah menerima pelajaran yang dapat dilihat secara visual daripada yang abstrak. Lama belajar di LSBA ini selama 3 tahun kuliah dan 1 tahun Pelatihan Kerja dimana siswa selama 1 tahun di latih untuk dapat memiliki konsep bekerja. Setiap mata kuliah durasi setiap pertemuan adalah satu setengah jam dan apabila lanjut ke sesi selanjutnya diselingi istirahat selama 30 menit.

Kurikulum yang diterapkan adalah kurikulum tersendiri yang terdiri dari jurusan Kriya Tekstil, Tehnik Cetak \& Digital Image, Administrasi Perkantoran. Melalui penerapan kurikulum tersebut maka kompetensi yang ingin dibentuk adalah siswa yang telah lulus dari LSBA mandiri, mampu memiliki keterampilan sesuai dengan program yang dipelajarinya sehingga dengan keterampilan yang dimiliki dapat membuka usaha secara mandiri. Atas dasar hal tersebut di atas maka peneliti tertarik mencoba untuk meneliti program apa yang paling tepat bagi anak autisma usia remaja. Peneliti juga menggali lebih dalam implementasi dari kurikulum yang diterapkan serta teknik pembejaran yang dilakukan. Penelitian ini menjadi menarik serta penting dilakukan mengingat 
masih minimnya lembaga pendidikan yang mengkhususkan bagi remaja autism. Selain itu hasil penelitian ini akan memberikan gambaran bagaimana persiapan program belajar direncanakan, diimplementasikan, dimonitoring, dan dievaluasi. Melalui penelitian ini diharapkan remaja autisma yang memiliki karakteristik berbeda dengan anak pada umumnya dapat memperoleh pembelajaran yang membentuk kompetensi tertentu. Dengan memiliki kompetensi tertentu, anak autisma diharapkan siap bekerja. Siap bekerja dimaksudkan terdiri dari dua kata yaitu kesiapan dan kerja dimana kesiapan meliputi kemampuan untuk menempatkan dirinya jika memulai serangkaian gerakan yang berkaitan dengan kesiapan mental dan jasmani (Chaplin, 2006).

Sementara itu menurut (Dalyono, 2005) kesiapan adalah kemampuan yang cukup, baik fisik maupun mental. Kesiapan fisik berarti tenaga yang cukup dan Kesehatan yang baik, sementara kesiapan mental yaitu memiliki minat dan motivasi yang cukup untuk melakukan suatu kegiatan.

(Djaali, 2008) berpendapat bahwa bekerja mengandung arti melaksanakan suatu tugas yang diakhiri dengan sebuah karya. Kesiapan kerja dipandang sebagai usaha untuk memantapkan seseorang mempersiapakan diri dalam menekuni sebuah pekerjaan (Winkel \& Hastuti, 2006). Menurut (Brady, 2009) kesiapan kerja berfokus pada sifat - sifat pribadi individu, seperti sifat sikap bekerja dan mekanisme pertahanan tubuh yang diperlukan dalam mendapatkan serta mempertahankan pekerjaan yang telah di dapat. (Pool \& Sewel, 2007) untuk memiliki kesiapan kerja yang tinggi diperlukan beberapa hal yaitu keahlian seesuai dengan bidangnya, kepribadian, kecerdasan dan wawasan yang luas, pemahaman dalam berpikir yang membuat seseorang dapat memilih serta merasa nyaman dengan pekerjaannya sehingga dapat meraih keberhasilan terutama dalam dunia kerja.

Menurut Brady (2009), terdapat enam aspek kesiapan kerja yaitu sebagai berikut:

Tanggung Jawab (Responsibility)

Tanggung jawab merupakan bentuk kesadaran individu dalam berperilaku untuk melaksanakan dan menyelesaikan tugas selama berada ditempat kerja meskipun tanpa adanya pengawasan dari orang lain. Individu yang siap untuk bekerja maka, memiliki perasaan atau keinginan untuk bertanggung jawab terhadap pekerjaannya. Tanggung jawab merupakan komponen penting yang harus dimiliki oleh individu dalam bekerja. Tanggung jawab melibatkan integritas pribadi, kejujuran, dan kepercayaan. Misalnya pekerja datang tepat waktu, pekerja bekerja sesuai dengan SOP yang telah ditentukan.

Fleksibilitas (Flexibility)

Fleksibilitas merupakan kemampuan individu dalam menyesuaikan diri dengan perubahan dan tuntutan ditempat kerja. Individu yang mampu memiliki fleksibilitas dapat menerima perubahan yang terjadi, baik itu perubahan yang dapat diprediksikan ataupun perubahan yang tidak dapat diprediksikan. Selain itu, individu dapat lebih aktif dan siap untuk menyesuaikan diri dengan perubahan pada jadwal kerja, jam kerja dan tugas-tugas dari tempat kerja.

Keterampilan (Skills)

Individu yang siap bekerja mengetahui mengenai kemampuan dan keahlian yang dimiliki untuk dibawa ke dalam situasi kerja baru. Mereka mampu mengidentifikasi keterampilan yang dimiliki sebagai kekuatan untuk untuk mengerjakan tugas ditempat kerja. Selain itu, mereka juga harus bersedia untuk mendapatkan keterampilan baru sesuai tuntutan pekerjaan dan berpartisipasi dalam pelatihan karyawan serta program pendidikan berkelanjutan.

Komunikasi (Communication)

Individu yang siap kerja memiliki kemampuan komunikasi yang dapat digunakan untuk berhubungan secara interpersonal ditempat kerja. Apabila individu mampu berkomunikasi dengan baik akan lebih mudah berinteraksi dan beradaptasi dengan lingkungan kerja yang baru. Selain itu, individu mampu untuk mengikuti perintah atau petunjuk, memahami bagaimana cara meminta bantuan, dapat menerima kritik dan masukan serta individu juga saling menghormati dan berhubungan baik dengan atasan maupun rekan kerja.

Pandangan diri (Self View)

Penulis1, Penulis2 (Cambria 9)

TATA CARA PENULISAN NASKAH JURNAL MANAJEMEN PENDIDIKAN (Huruf Capital, Cambria 9) | 49 
Pandangan diri (self view) berkaitan dengan proses intrapersonal individu, mengenai keyakinan tentang dirinya dan pekerjaan. Pandangan diri (self view) merupakan salah satu aspek yang penting dalam komponen kesiapan kerja, karena teori diri memiliki peranan yang penting dalam pemahaman terhadap individu dan bagaimana setiap orang memandang dirinya dalam hidup dan situasi kerja. Individu yang siap bekerja maka, mereka menyadari dengan kemampuan yang dimilikinya, penerimaan, keyakinan, dan rasa kepercayaan diri yang ada dalam diri mereka.

Kesehatan dan Keselamatan (Health \& Safety)

Individu yang siap kerja dapat menjaga kebersihan dan mampu merawat diri serta sehat secara fisik dan mental. Melalui jiwa yang sehat maka, individu dapat menggunakan atau mengoperasikan peralatan mesin yang terdapat ditempat kerja secara tepat sesuai dengan prosedur yang ada. Selain itu, individu dapat bersedia mengikuti kebijakan atau peraturan yang terdapat ditempat kerja untuk menjaga kesehatan dan keselamatan dengan memakai perlengkapan atau pakaian yang telah disediakan.

Berdasarkan uraian di atas, peneliti dapat menyimpulkan bahwa kesiapan kerja merupakan kemampuan individu baik secara mental maupun fisik untuk dapat menghadapi atau melakukan suatu pekerjaan yang membutuhkan keterampilan, pengetahuan, kecekatan dan pengalaman untuk dapat melakukan tugas pekerjaan yang harus diselesaikan dan merupakan tanggung jawabnya. Dalam hal ini kesiapan kerja bagi individu autisma yang dimaksudkan adalah individu autism ini memiliki bekal keterampilan dan keahlian yang mereka pelajari di LSBA. Dengan kelebihan yang mereka miliki yaitu mudah belajar secara visual dan praktek yang terus menerus, menjadikan mereka terbiasa dan terlatih dalam mengerjakan tugas atau pelatihan yang mereka laksanakan. Bahkan didapati kemampuan individu autisma ini melebihi dari individu pada umumnya. Misalnya dalam fotografi, terkadang tidak pernah tersirat oleh individu pada umumya untuk mengambil foto dengan engel yang seperti mereka lihat. Mereka dengan kelebihan dan keterbatasannya mampu memiliki keterampilan yang luar biasa. Atau hasil cetakan sablon hasil karya mereka lebih bagus baik kombinasi warna maupun desainnya.

Yang tak kalah menarik adalah karena mereka begitu on time dengan waktu baik waktu memulai atau menyelesaikan segala sesuatu, menjadikan mereka fokus untuk dapat menyelesaikan tugas yang mereka kerjakan. Sebagai contoh bahwa individu autisma ini bisa hanya membutuhkan waktu bekerja lebih cepat daripada individu lainnya. Karena apabila mereka mengerjakan sesuatu begitu fokus sampai dengan pekerjaan itu selesai, apabila pekerjaan itu belum selesai maka individu autisma tersebut tidak akan berhenti. Atau yang pernah terjadi yaitu seorang individu autisma saat berlatih memasukan data di komputer hanya membutuhkan waktu satu jam saja, karena individu autisma tersebut begitu fokus mengerjakannya tanpa perlu mengobrol atau sekedar bercengkrama dengan orang lain, sementara bagi individu tanpa hambatan pada umumnya, sering kita dapati bahwa mengerjakan tugas atau pekerjaan sambil berbicara, mengobrol atau mungkin mondar mandir untuk mengambil sesuatu, hal ini tidak terjadi pada individu autisma, karena mereka akan fokus dalam mengerjakan tugas atau pekerjaanya. Hal inilah maka pekerjaan atau tugas dapat diselesaikan dengan cepat. Hal ini yang menjadikan individu autisma tidak kalah dengan individu lainnya. Dengan keterbatasan serta kesulitan yang dialami individu autisma yaitu berupa kesulitan dari segi pemahaman bahasa, perilaku, sensori, emosi namun tidak menjadikan mereka tidak memiliki keahlian lebih dibandingkan individu tanpa hambatan lainnya.

Di LSBA, diakhir tahun mereka belajar konsep bekerja. Dimana selama tiga tahun mereka sudah belajar praktek dan di tahun ke empat, mereka mempraktekan semua mata pelajaran yang telah dipelajari dalam bentuk belajar bekerja dengan menerima orderan. Dari orderan ini, keuntungan seluruhnya diberikan ke semua siswa secara merata. Tujuan yang ingin disampaiakan ke individu autisma yang mengikuti program ini, agar mereka memahami konsep bekerja bahwa saat mereka bekerja dengan baik dan mematuhi aturan serta dapat menyelesaikan orderan tepat waktu, mereka akan mendapatkan honor dari keuntungan penjualan. Dengan ini pula individu siap untuk bekerja dengan memiliki keterampilan yang telah dipelajari di LSBA.

Dalam hal ini dapat peneliti ambil kesimpulan bahwa walaupun memiliki keterbatasan namun individu autisma juga memiliki kelebihan yang tidak berbeda dengan individu tanpa hambatan sehingga dengan kelebihan yang mereka miliki mereka mampu mempunyai keterampilan yang 
sama dengan individu pada umumnya, bisa mandiri dan mampu bekerja. Dengan praktek yang telah mereka ikuti dan pelajari, maka tidak menutup kemungkinan mereka mampu dan siap bekerja.

Di Indonesia autisma mulai dikenal belum terlalu lama, istilah "autism" pertama kali diperkenalkan oleh Eugene Bleuler tahun 1908 oleh Eugen Bleuler untuk pasien skizofrenia yang menunjukkan gejala menarik diri yang parah (Sariwati \& Handayani, 2018). Dimana perilaku yang nampak pada zkizofrenia dewasa terlihat sebagai perilaku autisma seperti berbicara sendiri tanpa ada orang lain, tiba - tiba tanpa sebab pasti marah - marah bahkan bisa marah besar dan tertawa terbahak - bahak sementara tidak ada hal yang lucu yang nampak. (Winarno, 2013) mengutip pendapat dari Kanner, seorang Psikiater dari Universitas John Hopkins (USA) pada tahun 1943 mengatakan bahwa Autisma merupakan kelainan yang terjadi pada anak yang tidak mengalami perkembangan normal, khususnya dalam hubungan dengan orang lain, berkelakuan memberontak dan melakukan tindakan berulang - ulang dan biasanya tampak jelas setelah anak mencapai usia 3 tahun.

Hal lain lagi yaitu menanyakan atau mengucapkan kata yang sama dan berulang - ulang dengan intonasi yang kaku dan terlihat seperti suara robot ini dilakukan kepada semua orang bahkan akan menyampaikan lagi kepada orang yang sama berulang - ulang seakan - akan lupa bahwa tadi sudah menyampaikan atau menanyakan hal yang sama (Winarno, 2013). Efektivitas berasal dari kata efektif yang mengandung pengertian dicapainya keberhasilan dalam mencapai tujuan yang telah ditetapkan. Efektivitas selalu terkait dengan hubungan antara hasil yang diharapkan dengan hasil yang sesungguhnya dicapai. Menurut Kurniawan (2005) Efektivitas adalah kemampuan melaksanakan tugas, fungsi (operasi kegiatan program atau misi) daripada suatu organisasi atau sejenisnya yang tidak adanya tekanan atau ketegangan diantara pelaksanaanya.

Sementara dalam Kamus Besar Bahasa Indonesia kata efektif didefinisikan dengan "ada efeknya (akibatnya, pengaruhnya, kesannya)" atau "dapat membawa hasil, berhasil guna (usaha, tindakan)" dan efektivitas diartikan "keadaan berpengaruh; hal berkesan" atau" keberhasilan (usaha, tindakan)". Efektivitas merupakan suatu kemampuan untuk memiliki tujuan yang tepat atau mencapai tujuan yang telah ditetapkan.

Efektivitas program menurut Subagyo (2000) dapat diukur mengunakan indikator sebagai berikut

Ketepatan Sasaran Program

Ketepatan sasaran program yaitu sejauh mana peserta program tepat dengan sasaran yang sudah ditetapkan sebelumnya.

Hal ini dapat dikatakan bahwa program yang telah direncanakan atau dirancang tepat mengenai tujuan atau sasaran yang hendak dituju sehingga sesuai dengan rencana yang telah ditetapkan atau dibuat.

Sosialisasi Program

Sosialisasi program yaitu kemampuan pelaksana program dalam melakukan sosialisasi program sehingga informasi mengenai pelaksanaan program dapat tersampaikan kepada masyarakat pada umumnya dan sasaran peserta program pada umumnya.

Perencana program ini melakukan kegiatan sosialisasi sehingga informasi dari suatu program yang telah direncanakan dapat dimengerti atau dipahami oleh peserta program tersebut sehingga peserta program tersebut dapat mengetahui dengan jelas tujuan dari program yang dibuat.

Tujuan Program

Tujuan Program adalah sejauh mana kesesuaian antara hasil pelaksanaan program dengan tujuan program yang telah ditetapkan sebelumnya.

Dengan kata lain, program yang telah dibuat pelaksanaannya harus sesuai dengan tujuan dari rencana program tersebut sehingga tepat guna.

Pemantauan Program

Pemantauan program merupakan kegiatan yang dilakukan setelah dilaksanakanya program sebagai bentuk perhatian kepada peserta program.

Pemantauan program ini dilakukan guna untuk melihat seberapa berhasilnya pelaksanaan program yang telah direncanakan yang dapat dipahami oleh peserta. Apa yang perlu diperbaiki dan apa yang perlu ditambahkan menjadi bagian dari pemantauan program ini supaya dapat tepat sesuai dengan tujuan yang diharapkan. 
Sementara itu menurut (Sutrisno, 2007) efektivitas program dapat diukur. Adapun ukuran tersebut terdiri dari :

Pemahaman Program

Dalam hal ini untuk melihat pemahaman dari peserta atau siswa yang mengikuti program LSBA. Dengan adanya program pendidikan ini maka semua hal yang direncanakan akan lebih terorganisir dan lebih mudah untuk dilaksanakan.

Tepat Sasaran

Bahwa program yang telah direncanakan apakah sesuai dengan individu autisma yang belajar di LSBA, apakah rencana yang dibuat sesuai dengan sasaran yang hendak dicapai, hal ini penting diperhatikan sehingga program yang dibuat tidak sia - sia.

Tepat Waktu

Yaitu apakah pelaksanaan program yang telah dibuat tepat waktu dengan kata lain apakah sesuai dengan jadwal yang telah direncanakan. Dengan perhitungan waktu yang tepat maka program ini akan efektif.

Tercapainya tujuan

Dalam hal ini, apakah program yang telah dibuat dapat mencapai apa yang di targetkan atau dituju. Apabila program yang direncanakan dapat mencapai tujuan yang telah ditentukan sebelumnya maka program ini dapat dikatakan efektif.

Perubahan nyata

Perubahan apa yang terjadi saat ada atau sebelum program ini dilaksanakan. Perubahan nyata yang bagaimana yang terlihat saat menggunakan program ini. Apabila terdapat perubahan nyata dari individu autisma yang belajar menggunakan program di LSBA maka dapat dikatakan program ini efektif.

\section{METODE PENELITIAN}

Metode penelitian yang digunakan oleh peneliti adalah kualitatif yaitu penelitian untuk memahami fenomena tentang apa yang dialami oleh subjek penelitan secara holistic dan dengan cara deskripsi dalam bentuk kakat - kata dan bahasa, pada suatu konteks khusus yang alamiah dan dengan memanfaatkan berbagai metode ilmiah (Moleong, 2007). Adapun jenis pendekatan penelitian ini adalah deskriptif yaitu penelitian untuk menuturkan pemecahan masalah yang ada sekarang berdasarkan data - data. Jenis. penelitian deskriptif kualitatif yang digunakan dalam penelitian ini dimaksudkan untuk memperoleh informasi dengan metode penelitian yang digunakan yaitu metode penelitian kualitatif. Metode ini dirasa tepat oleh peneliti karena dapat memberikan gambaran secara utuh bagaimana program di LSBA melalui tahapan perencanaan, implementasi, monitoring serta evaluasi.

Adapun narasumber dipilih untuk menjadi data primer atau informan adalah: Direktur LSBA sebanyak 1 orang, Manager LSBA sebanyak 1 orang, Koordinator Akademik sebanyak 1 orang dan Koordinator Balai Latihan Kerja sebanyak 1 orang. Sesuai dengan rumusan masalah dan tujuan penelitian sebagaimana telah disebutkan pada bagian pendahuluan di atas maka fokus penelitian ini adalah perencanaan, pelaksanaan, monitoring dan evaluasi penyelenggaraan pendidikan autisma yang dilaksanakan oleh London School Beyond Academy (LSBA) dapat memberikan kompetensi khusus kepada individu autisma sebagai pegangan bagi kariernya di masyarakat. Peneliti menggunakan 4 kategori dalam penelitiannya yaitu Perencanaan, Implementasi, Monitoring, dan Evaluasi. Teknik pengumpulan data yang digunakan oleh peneliti berdasarkan wawancara, observasi dokumentasi. Teknik analisis data yang digunakan (Sugiyono, 2011) adalah reduksi data, penyajian data, dan penarikan kesimpulan.

\section{HASIL DAN PEMBAHASAN}

Efektivitas Perencanaan Kurikulum

Dalam temuan yang didapat peneliti melalui wawancara maupun dokumen, peneliti melihat bahwa kurikulum atau program LSBA ini direncanakan dengan cukup baik dilihat dari temuan yang 
peneliti temui yaitu sebelum perencanaan program dipelajari lebih dahulu mengenai karakteristik autisma, kelebihannya, kelemahannya, apa yang dibutuhkan individu autisma yang sudah lulus SMA. Dan adanya kompetensi yang menjadi tujuan dari pemberian program autisma di LSBA ini. Peneliti melihat adanya detail kebutuhan dan tujuan yang ingin dicapai berdasarkan kebutuhan individu autisma yang pasti beragam kemampuannya.

Perencanaan kurikulum dengan melihat kondisi rentang kefokusan individu autisma yang pendek menjadikan pertimbangan utama dalam perencanaan kurikulum ini. Dan adanya rasa ingin memberikan harapan bagi individu - individu autisma yang akan menjadi lebih baik, menjadikan LSBA mencoba untuk berkontribusi dalam hal itu. Dan adanya rancangan bahwa saat belajar mengajar di dalam kelas, diperlukan dua orang yaitu pengajar utama dan guru pendidikan luar biasa yang bekerjasama untuk perkembangan yang lebih baik bagi individu autisma ini. Karena itu peneliti melihat bahwa perencanaan kurikulum ini efektif digunakan untuk individu autisma.

\section{Efektivitas Implementasi Kurikulum}

Peneliti mendapatkan gambaran yang positif mengenai implementasi kurikulum dari narasumber. Implementasi pelaksanaan kurikulum ini cukup baik sangat bervariasi dan tidak kaku. Semua dilakukan sesuai dengan kebutuhan dan kemampuan individu autisma di LSBA. Dari mulai pelaksanaan belajar mengajar di kelas yang menggunakan berbagai metode, cara maupun sarana dan prasarana yang disiapkan sehingga pengajaran di kelas tidak membosankan dan kreatif menjadikan siswa di LSBA dapat memahami pengajaran yang diberikan terlebih sesuai informasi narasumber menyampaikan bahwa siswa - siswa LSBA memiliki minat yang cukup besar saat belajar dengan kata lain siswa LSBA tertarik dan sangat menikmati belajar di LSBA. Namun demikian terkadang juga ada hambatan terutama saat program sudah berjalan namun ternyata tidak sesuai dengan minat dari siswa LSBA tersebut dan juga tidak sesuai dengan kemampuannya sehingga siswa kurang dapat menerima materi yang disampaikan. Oleh karena itu dalam implementasi ini penempatan siswa sangat fleksisbel sehingga apabila dinilai siswa tidak mampu mempelajari program pilihan maka akan dipindahkan sesuai kemampuan siswa dengan berdasarkan penilaian.

\section{Efektivitas Monitoring Kegiatan Belajar Mengajar}

Dalam monitoring ini peneliti mendapat informasi dari narasumber - narasumber yang telah peneliti wawancara. Di monitoring ini sudah dilakukan secara berkala, baik harian, tengah semester, akhir semester. Dan monitoring ini dilakukan secara rutin. Hal ini peneliti lihat sangat positif, sehingga apabila ada ketidaksesuaian maka dapat diambil tindakan pencegahan sehingga tidak berlarut - larut dan menimbulkan masalah pada akhir semester. Dengan adanya monitoring ini untuk dapat memastikan bahwa seluruh kegiatan berjalan seperti yang telah dirancang dan ketika terjadi ketidaksesuaian maka tindakan perbaikan dapat langsung dilakukan. Karena itu menjadikan siswa tidak dirugikan dan meningkatkan perkembangan seluruh siswa autisma di LSBA. Hanya disini ada informasi yang berbeda dari salah satu narasumber yang menyampaikan bahwa diperlukan lebih banyak lagi komunikasi dengan orang tua sehingga apa yang telah didapat di LSBA dapat diajarkan kembali di rumah dan perlu diperbanyak pelajaran yang bersifat praktek juga perlu di perdalam lagi program pengajaran yang diberikan sehingga siswa LSBA dapat lebih menguasai materi yang diajarkan. Sehingga dapat disimpulkan bahwa monitoring di LSBA efektif dengan selalu memantau pelaksanaan program di lapangan, sehingga apabila ditemukan ketidaksesuaian, tanpa menunggu lama akan dilakukan tindakan sehingga permasalahan yang timbul dapat segera diberikan solusi.

\section{Efektivitas Evaluasi Kegiatan Belajar Mengajar}

Peneliti mendapatkan dari beberapa narasumber yang telah peneliti wawancarai. Peneliti mendapatkan hal positif dengan adanya evaluasi ini baik akademik maupun non-akademik, dimana dilaksanakan secara periodik. Evaluasi ini dilakukan setiap akhir semester untuk evaluasi akademik namun untuk evaluasi program secara keseluruhan dilakukan selama tiga tahun sekali. Hal ini dilakukan untuk melihat apabila ada ketidakselarasan dalam pengajaran di LSBA sehingga program 
yang berjalan di LSBA perlu ditingkatkan menjadi lebih baik atau harus diubah supaya menjadi lebih baik lagi. Dalam evaluasi ini dilakukan oleh Direktur LSBA, Manager LSBA, Koordinator Akademik, Koordinator Balai Latihan Kerja bersama - sama melihat program yang ada apakah sudah sesuai dan menjadikan individu autisma memiliki keterampilan dan atau kecakapan yang sesuai dengan apa yang telah direncanakan. Di bagian evaluasi ini maka bagian program yang sekiranya terlalu sulit untuk individu autisma atau diajarkan namun tidak membuat individu autisma mendapatkan perkembangan kemampuan keterampilan yang signifikan maka bagian program tersebut akan diperbaharui sehingga seluruh program yang ada di LSBA diharapkan dapat meningkatkan kemampuan keterampilan yang bermanfaat dikemudian hari. Prinsip LSBA adalah memberikan program terbaik yang dapat untuk mempersiapkan individu autisma memiliki keterampilan yang dapat digunakan untuk bekerja atau berwirausaha secara mandiri.

Pembahasan Hasil Penelitian

\section{Efektivitas Perencanaan Kurikulum}

Hasil penelitian menunjukan bahwa efektivitas program pendidikan terhadap individu autisma ternyata terbukti efektif sehingga secara signifikan individu autisma yang belajar di LSBA menggunakan program yang direncanakan mengalami perkembangan yang baik. Seperti yang dikemukakan oleh Kurniawan (2005) yang dimaksud dengan Efektivitas adalah kemampuan melaksanakan tugas, fungsi (operasi kegiatan program atau misi) daripada suatu organisasi atau sejenisnya yang tidak adanya tekanan atau ketegangan di antara pelaksanaannya. Pernyataan tersebut memberi arti bahwa penyelenggaraan efektivitas program pendidikan ini ditujukan untuk meningkatkan kemampuan dari individu autisma disesuaikan dengan kemampuan masing - masing individu yang secara kemampuan memiliki kesulitan baik pemahaman, emosi, perilaku dan komunikasinya. Dari hasil siswa yang belajar di LSBA ada perubahan yang signifikan terhadap siswa yang belajar di LSBA sesuai dengan yang disampaikan narasumber kepada peneliti. Sehingga apabila efektivitas program pendidikan ini memiliki hubungan dengan individu autisma adalah merupakan suatu hal yang wajar dan baik. Efektivitas program pendidikan yang dilaksanakan dengan metode, sarana prasarana, kemampuan yang terstruktur dan pengajar yang kompeten maka individu autisma yang belajar akan memahami dan mengalami peningkatan dalam perkembangannya.

Efektivitas Implementasi Kurikulum

Hasil penelitian ini juga membuktikan bahwa efektivitas implementasi kurikulum pendidikan ternyata efektif dan signifikan bagi individu autisma. Implementasi pelaksanaan kurikulum ini dalam kegiatan belajar mengajar cukup baik sangat bervariasi dan tidak kaku. Menjadikan siswa autisma yang belajar tidak merasa dibawah tekanan saat belajar. Penggunaan sarana dan prasarana serta metode belajar yang bervariasi menjadikan siswa mampu mengikuti pelajaran dengan baik dengan hasil seperti yang diharapakan sesuai dengan rencana kurikulum yang telah dirancang. Semua dilakukan sesuai dengan kebutuhan dan kemampuan individu autisma di LSBA

Efektivitas Monitoring Kegiatan Belajar Mengajar

Dari hasil penelitian, monitoring dilakukan dengan baik, monitoring di LSBA ini dilakukan secara berkala diharapkan dengan monitoring ini segala ketidaksesuaian dalam pelaksanaan kurikulum di dalam kegiatan belajar mengajar dapat diminimalisir. Dan dari hasil penelitian ini ternyata terbukti bahwa monitoring efektif dilakukan di LSBA. Dikarenakan karakteristik individu autisma yang lebih mudah memahami pelajaran dengan visual daripada teori, maka hal ini sudah tepat dilakukan di LSBA. Dengan monitoring yang berkala ini menjadikan pengawasan lebih mudah dan apabila ada kesalahan bisa segera diperbaiki.

Efektivitas Evaluasi Kegiatan Belajar Mengajar

Peneliti mendapatkan hasil dari penelitian ini bahwa ternyata evalausi yang dilakukan dalam kegiatan belajar mengajar efektif dilakukan di LSBA terutama untuk mengevaluasi kurikulum yang dilaksanakan didalam pengajaran di kelas bagi individu autisma. Evaluasi ini menjadikan mengetahui bagian - bagian atau hal - hal yang perlu ditambah, dikurangi atau dihilangkan. Dengan 
evaluasi ini juga meembuat LSBA tetap terjaga kualitas penddikannya, terutama untuk individu autisma.

Hasil penelitian ini juga membuktikan bahwa efektivitas evaluasi program pendidikan ternyata terbukti efektif untuk persiapan kerja bagi individu autisma. Hal ini dapat dipahami seperti yang disampaikan oleh Tangkilisan bahwa adaptasi yang baik di tempat kerja maka mempengaruhi mood dari setiap pekerja sehingga menjadikan meningkatnya kualitas kerja yang baik dan pastinya akan mempengaruhi kuantitas hasil kerja. Ini membuktikan bahwa dengan program di LSBA mempunyai hubungan positif karena program ini telah menjadikan individu autisma memiliki ketrampilan dan dengan program yang dilaksanakan melatih individu - individu ini untuk dapat bekerja seperti yang disampaikan oleh narasumber yang menyampaikan bahwa putranya dapat beradaptasi dan menjadi semakin tanggung jawab dan siap kerja dengan keterampilan yang di pelajari di LSBA.

\section{KESIMPULAN}

\section{Kesimpulan}

Berdasarkan analisis dan pembahasan pada dapat disimpulkan hal-hal sebagai berikut: (1)Proses penentuan serta pembentukan kurikulum mata kuliah serta tugas sudah dilakukan dengan baik oleh Lembaga Keterampilan Pelatihan (LKP) LSBA dan terbukti penentuan pembentukan kurikulum ini tepat dilakukan untuk individu autisma. (2) Proses penerapan mata kuliah baik yang bersifat teori maupun praktek sudah dilaksanakan dengan baik oleh LSBA dengan prosentase penilaian praktek sebanyak delapan puluh lima persen, teori sebanyak lima belas persen, ternyata terbukti dengan prosentase belajar praktek lebih besar dibandingkan dengan teori ini tepat dilakukan untuk individu autisma. (3) Proses untuk memastikan bahwa pelaksanaan kegiatan belajar mengajar sesuai dengan kompetensi yang direncanakan sudah dilakukan dengan baik oleh LSBA dengan adanya laporan harian dari pengajar juga dari tugas yang telah dikerjakan oleh siswa dan terbukti efektif untuk memastikan kegiatan belajar mengajar berjalan dengan baik bagi individu autisma. (4) Proses evaluasi kegiatan belajar mengajar dalam tataran mata kuliah, hasil akhir, dan capaian kompetensi sudah dilakukan oleh LSBA dan terlaksana dengan baik. Evaluasi ini dilakukan dengan adanya ujian tengah semester dan akhir semester yang dilakukan baik secara teori maupun praktek ternyata terbukti efektif evaluasi yang dilakukan di LSBA.

\section{Implikasi}

Dengan mengacu pada hasil penelitian yang menyimpulkan bahwa program pendidikan dapat mempersiapkan individu autisma untuk bekerja, maka implikasinya adalah :

Perencanaan Program di LSBA dengan melihat karakteristik individu autisma, dimana salah satu karakternya tingkat kefokusannya pendek sehingga program yang direncanakan tidak padat seperti individu pada umumnya. Dan dikarenakan individu autisma lebih mudah belajar dengan cara visual maka dalam program di LSBA ini dibuat belajar secara praktek lebih banyak yaitu delapan puluh lima persen dan teori hanya lima belas persen; Implementasi kurikulum di LSBA di dalam kegiatan belajar mengajar sesuai hasil penelitian sudah terlaksana, dengan tersedianya sarana dan prasarana yang mendukung, dalam mengajar di kelas kolaborasi dua orang yaitu pengajar utama dan guru kebutuhan khusus, hasil belajar sesuai dengan rencana kurikulum yang telah ditetapkan walaupun didapati ada siswa yang masih membutuhkan waktu yang lebih panjang dalam memahami pengajaran di kelas karena itu rentang belajar lebih diperpanjang; Monitoring kegiatan belajar mengajar yang dilakukan dengan laporan harian mengenai apa yang diajarkan untuk melihat sesuai atau tidaknya dengan kurikulum yang sudah direncanakan, tugas apa yang sudah dikerjakan oleh siswa dan hasil yang didapatkan seperti apa, apabila tidak ada kesesuaian maka dilakukan perbaikan; Evaluasi kegiatan belajar mengajar yang dilakukan di LSBA untuk dapat melihat kemampuan siswa autisma dalam memahami materi yang diberikan sesuai dengan rencana program yang telah dibuat. Minat dan kemampuan siswa dapat terlihat saat diadakan evaluasi, apabila didapatkan bahwa siswa autisma mengalami kesulitan memahami pelajaran berdasarkan hasil evaluasi, maka akan dibuat penyesuaian jurusan yang sesuai dengan kemampuanya. 
Saran

Berdasarkan kesimpulan dan implikasi hasil penelitian, maka saran yang perlu ditindak lanjuti antara lain :

Seyogyanya proses penentuan serta pembentukan kurikulum mata kuliah serta tugas telah direncanakan sebaiknya ditingkatkan lagi terutama dari penambahan waktu belajar karena terbukti adanya hal positif antara program LSBA dengan individu autisma untuk persiapan bekerja. Sehingga dengan adanya program di LSBA ini dapat menambah pengetahuan dan wawasan baik untuk masyarakat maupun pemerintah bahwa program di LSBA dapat menjadi salah satu program yang tepat bagi individu autism; Sebaiknya proses penerapan mata kuliah baik bersifat teori maupun praktek yang sudah dilaksanakan dengan baik perlu ditingkatkan dengan memberikan latihan - latihan praktek lebih banyak lagi; Disarankan proses untuk memastikan pelaksanaan kegiatan belajar mengajar apa sudah sesuai dengan kompetensi yang direncanakan dapat juga dilakukan dengan setiap bulan siswa diminta membuat proyek yang berhubungan dengan kegiatan praktek sehingga dapat lebih dipastikan lagi kemampuan siswa dalam memahami materi pelajaran yang dipelajari di LSBA; Diharapkan evaluasi kegiatan belajar mengajar dalam tataran mata kuliah, hasil akhir, dan capaian kompetensi evaluasi kegiatan belajar mengajar di LSBA yang sudah berjalan dengan baik ditambahkan dengan pembuatan proyek keterampilan yang telah dipelajari selama tiga tahun di LSBA.

\section{DAFTAR PUSTAKA}

1. Brady, R. (2009). Kesiapan Kerjs bagi Inventaris Administrator. Jakarta: Akasia.

2. Chaplin, J. (2006). Kamus Lengkap Psikologi (Terjemahan Kartini Kartono). Jakarta: PT Raja Grafindo Persada.

3. Dalyono. (2005). Psikologi Pendidikan. Jakarta: Rineka Cipta.

4. Djaali. (2008). Psikologi Pendidikan. Jakarta: Bumi Aksara.

5. Kementerian Pendidikan dan Kebudayaan Indonesia. (2017, Februari 1). Kementerian Pendidikan dan Kebudayaan Indonesia. Retrieved from Sekolah Inklusi dan Pembangunan SLB Dukung Pendidikan Inklusi: https://www.kemdikbud.go.id/main/blog/2017/02/sekolahinklusi-dan-pembangunan-slb-dukung-pendidikan-inklusi

6. Kurniawan, A. (2005). Transformasi Pelayanan Publik. Yogyakarta: Pembaruan.

7. Moleong, L. (2007). Metodologi Penelitian Kualitatif. Edisi Revisi. Bandung: PT Remaja Rosdakarya.

8. Pool, L., \& Sewel, P. (2007). The Key to Employability: Developing A Pratical Model of Graduate Employability. Education and Training; 49(4), 277-289.

9. Sariwati, D., \& Handayani, M. (2018). Training of Trainer Penanganan Anak Dengan Gangguan Spektrum Autisme Bagi Guru Sekolah Luar Biasa dan Guru Pembimbing Khusus Sekolah Inklusi Se-Jawa Timur. Jurnal Layanan Masyarakat Universitas Airlangga, 2(2), 78-82.

10. Subagyo, A. W. (2000). Efektivitas Program Penanggulangan Kemiskinan Dalam Pemberdayaan Masyarakat Pedesaan. Yogyakarta: UGM.

11. Sugiyono. (2011). Metode Penelitian Kuantitatif, Kualitatif dan R\&D. Bandung: Afabeta.

12. Sutrisno, E. (2007). Manajemen Sumber Daya Manusia. Jakarta: Kencana.

13. Winarno, F. (2013). Autisme dan Peran Pangan. Jakarta: Gramedia Pustaka Utama.

14. Winkel, W., \& Hastuti, S. (2006). Bimbingan dan Konseling di Institusi Pendidikan. Yogyakarta: Media Abadi. 